\title{
PENJERNIHAN AIR DENGAN SARINGAN PASIR \\ DAN DESINFEKTAN ALAMI
}

\author{
Soehartono *)
}

\begin{abstract}
Abstrak
Air kotor dapat membahayakan bagi kesehatan dan keselamatan jiwa bagi manusia, yang bisa menjadikan wabah penyakit kolera, kurap, kudis, diare/disentri dan tipus adalah sebagian dari penyakit yang timbul dari air kotor yang tetap dikonsumsi tanpa pengolahan yang lebih lanjut.

Kebutuhan akan air bersih untuk konsumsi masyarakat masih terhambat dikarenakan air kotor dan sumber air yang ada tidak didayagunakan secara maksimal. Salah satu sumber air baku yang mudah diperoleh adalah air sungai, tetapi masih dikatagorikan/tergolong sebagai air kotor dikarenakan masih banyaknya masyarakat yang membuang limbah ke sungai.

Untuk mengatasi air kotor dari sungai solusi dengan sistem penyaringan air sungai dengan menggunakan metode penjernihanpasir, dengan dua kali tahapan yang menggunakan penjernihandan desinfeksi alami menggunakan biji kelor, selain itu dalam konsep ini kita memanfaatkan gaya ke atas air (upflow).

Dengan sistem penyaringan ini diharapkan dapat menghasilkan air yang memenuhi standar air bersih yang dapat diminum serta memenuhi standar kesehatan dan dapat dikonsumsi bagi masyarakat di daerah aliran sungai bahkan bisa menyuplai ke daerah yang kekurangan air bersih, sehingga masyarakat mengkonsumsi air dengan standar kualitas kesehatan.
\end{abstract}

Keyword: Penjernihan Air, Dengan Pasir \& Biji Kelor

\section{PENDAHULUAN}

Air adalah kebutuhan dasar bagi kehidupan, karena kehidupan manusia sangat bergantung pada air, terutama adanya air bersih. Mulai dari penggunaan untuk kebutuhan rumah tangga antara lain ; mencuci, mandi, minum, industri, dan pertanian. Banyak wilayah Indonesia yang menderita kekeringan rutin tiap tahunnya, bahkan banyak pula yang krisis air bersih.

Dalam sistem penyediaan air bersih, sumber air merupakan satu komponen yang mutlak harus ada, karena tanpa sumber air sistem penyediaan air tidak akan berfungsi, dengan mengetahui akan karakteristik masing-masing sumber air serta faktor-faktor yang mempengaruhinya, diharapkan dapat membantu di dalam pemilihan air baku untuk suatu sistem penyediaan air bersih, serta mempermudah

tahapan selanjutnya di dalam pemilihan tipe dari pengolahan untuk menghasilkan air yang memenuhi standar kualitas secara fisik, kimiawi dan bakteriologis.

Air sungai merupakan sumber air baku yang melimpah dibandingkan sumber air baku yang lain, seperti halnya air tanah yang volumenya dipengaruhi oleh musim, jika musim kemarau ketersediaan air terbatas dan juga sebaliknya jika musim hujan ketersediaan air melimpah.

\footnotetext{
* Dosen Jurusan Teknik Sipil Fakultas Teknik Universitas Pandanaran
} 
Sungai juga banyak sekali manfaatnya, terutama sebagai sumber air baku untuk air minum atau untuk kebutuhan mandi cuci kakus (MCK) Tetapi pada kenyataannya oleh masyarakat umum dalam penggunaan sumber air minum

masih jarang digunakan karena kandungan air sungai yang kotor.

\section{Tujuan}

Tujuan adalah merumuskan suatu konsep untuk pemanfaatan di daerah aliran sungai atau daerah yang sering kekurangan air bersih yang bertujuan untuk mengubah air sungai yang kotor menjadi air bersih yang dapat digunakan oleh warga sekitar khususnya yang berada di daerah aliran sungai dan yang minim

akan kebutuhan air bersih.

\section{Manfaat}

Konsep diharapkan bermanfaat sebagai upaya untuk pengadaan air bersih ke tempat penduduk khususnya di daerah yang kekurangan air bersih, konsep pengaliran dan penyaringan air ini dapat menanggulangi banjir, pemerataan air bersih dan membuat air lebih ekonomis/tidak mahal juga mudah didapat. Desain konsep ini yaitu dengan membuat saluran sebelum sungai dibendung lalu mengalirkan ke petak-petak pengaliran yang berisi arang, ijuk dan biji kelor yang akan ditampung di bak penampung dan selanjutnya disalurkan ke perumahan penduduk di sekitar daerah aliran sungai.

\section{Sumber Air Minum}

\section{Air Permukaan.}

Adalah air hujan yang mengalir di permukaan bumi, pada umumnya air permukaan ini akan mendapat pencemaran selama pengalirannya, misalnya oleh lumpur, batang-batang kayu, daun-daun, kotoran industri kota dan sebagainya.

Air Permukaan ada 2 (dua) macam yaitu :

\section{a. Air Sungai}

Dalam penggunaannya untuk air minum, haruslah mengalami suatu pengolahan yang sempurna, karena air sungai mempunyai derajat pencemaran yang sangat tinggi sekali.

\section{b. Air Rawa/Danau}

Kebanyakan air rawa ini berwarna yang disebabkan oleh zat-zat organis yang telah membusuk, dengan adanya pembusukan kadar air zat organis tinggi, maka umumnya kadar Fe dan Mn akan tinggi pula dan dalam keadaan kelarutan

$\mathrm{O}_{2}$ kurang sekali, maka unsur-unsur $\mathrm{Fe}$ dan Mn ini akan larut.

\section{Syarat - Syarat Air Minum}

1. Syarat Fisik :

Syarat-syarat fisik dapat dilihat dari kekeruhan air dan warna harus dipenuhi oleh setiap jenis air minum di mana dilakukan penyaringan dalam pengolahannya, kadar/bilangan yang diisyaratkan dan tidak boleh dilampaui adalah sebagai berikut : 


\begin{tabular}{|l|c|c|}
\hline & $\begin{array}{c}\text { Kadar yang } \\
\text { (bilangan) } \\
\text { diisyaratkan }\end{array}$ & $\begin{array}{c}\text { Kadar yang } \\
\text { (bilangan) } \\
\text { ang tak } \\
\text { boleh } \\
\text { dilampaui }\end{array}$ \\
\hline $\begin{array}{l}\text { Keasaman } \\
\text { sebagai PK }\end{array}$ & $7,0-8,5$ & $\begin{array}{c}\leq 6,5 \text { dan } \\
\geq 9,5\end{array}$ \\
\hline $\begin{array}{l}\text { Bahan- } \\
\text { bahan padat }\end{array}$ & $\begin{array}{c}\text { Tak melebihi } \\
\text { Warna } \\
\text { (skala Pt } \\
\text { CO) }\end{array}$ & $\begin{array}{c}\text { Tak melebihi } \\
1500 \text { mg/l }\end{array}$ \\
\hline Rasa melebihi & Tak melebihi \\
& satuan & 50 kesatuan \\
Bau & Tak & - \\
\hline
\end{tabular}

2. Syarat-Syarat Bakteriologik

Air minum tidak boleh mengandung bakteri-bakteri penyakit (patogen) sama sekali dan tak boleh mengandung bakteri-bakteri golongan Coli melebihi batas-batas yang telah ditentukan yaitu $1 \mathrm{Coli} / 100 \mathrm{ml}$ air, dalam pemeriksaan

bakteriologik, diperiksa dengan indikator bakteri golongan Coli.

\section{Standar Kualitas Air Minum}

Adapun parameter penilaian kualitas air minum yang tercantum pada berbagai peraturan tentang Standar kualitas air minum tersebut di atas khususnya yang tertera pada
01/BIRHUKMAS/I/1975, yaitu :

1.Pengaruh adanya unsur-unsur tersebut dalam air

2. Sumber/asal unsur-unsur tersebut

3. Beberapa sifat yang perlu diketahui dari unsur tersebut

4.Efek yang dapat ditimbulkan terhadap kesehatan manusia

5. Alasan mengapa unsur tersebut dicantumkan dalam standar kualitas.

\section{3.a Proses Pengolahan Air}

1) Pengolahan Physics : Suatu tingkat pengolahan yang bertujuan untuk mengurangi/menghilangkan kotorankotoran yang kasar, penyisihan lumpur dan pasir, serta mengurangi kadar zat-zat organik yang ada dalam air yang akan diolah

2) Pengolahan Kimia : Suatu tingkat pengolahan dengan menggunakan zat-zat kimia untuk membantu proses pengolahan selanjutnya

3) Pengolahan Bakteriologis : Suatu tingkat pengolahan untuk membunuh bakteri-bakteri yang terkandung dalam air minum.

\section{3.b Desinfektan Alami}

Biji kelor ternyata merupakan penjernih air yang baik, biji kelor bersifat koagulan atau pengendap, mampu mengendapkan kotoran berupa partikel sangat kecil yang larut dalam air dengan cara 
mengikat partikel - partikel tersebut. Secara umum, satu biji kelor dapat menjernihkan 1 liter air, namun hal itu dipengaruhi juga oleh tingkat kekeruhan airnya. Hebatnya, biji kelor tidak hanya sekedar menjernihkan air, namun juga bisa membunuh kuman dan bakteri yang terkandung di dalam air karena adanya kandungan senyawa antibiotik di dalam biji kelor tersebut.

1. Desinfektan didefinisikan sebagai bahan kimia atau pengaruh fisika yang digunakan untuk mencegah terjadinya infeksi atau pencemaran jasad renik seperti bakteri dan virus, juga untuk membunuh atau menurunkan jumlah mikroorganisme atau kuman penyakit lainnya.

2. Sedangkan antiseptik didefinisikan sebagai bahan kimia yang dapat menghambat atau membunuh pertumbuhan jasad renik seperti bakteri, jamur dan lain-lain pada jaringan hidup. Bahan desinfektan dapat digunakan untuk proses desinfeksi tangan, lantai, ruangan, peralatan dan pakaian (Signaterdadie, 2009).

3. Pada dasarnya ada persamaan jenis bahan kimia yang digunakan sebagai antiseptik dan desinfektan. Tetapi tidak semua bahan desinfektan adalah bahan antiseptik karena adanya batasan dalam penggunaan antiseptik. Antiseptik tersebut harus memiliki sifat tidak merusak jaringan tubuh atau tidak bersifat keras. Terkadang penambahan bahan desinfektan juga dijadikan sebagai salah satu cara dalam proses sterilisasi, yaitu proses pembebasan kuman. Tetapi pada kenyataannya tidak semua bahan desinfektan dapat berfungsi sebagai bahan dalam proses sterilisasi.

Biji buah kelor (Moringan oleifera) mengandung zat aktif rhamnosyloxy-benzilisothiocyanate, yang mampu mengadopsi dan menetralisir partikel-partikel lumpur serta logam yang terkandung dalam air limbah suspensi, dengan partikel kotoran melayang di dalam air. Penemuan yang telah dikembangkan sejak tahun 1986 di Negeri Sudan untuk menjernihkan air dari anak Sungai Nil dan tampungan air hujan ini di masa datang dapat dikembangkan sebagai penjernih air Sungai Mahakam dan hasilnya dapat dimanfaatkan PDAM setempat.

Kandungan logam besi (Fe) dalam air Sungai Mahakam yang sebelumnya mencapai 3,23 mg/l, setelah dibersihkan dengan serbuk biji kelor menurun menjadi $0,13 \mathrm{mg} / \mathrm{l}$, dan telah memenuhi standar baku mutu air minum, yaitu $0,3 \mathrm{mg} / \mathrm{l}$ dan standar baku mutu air bersih 1,0 mg/l.

\section{3.b.1 Sinar Matahari}

Diperoleh data penurunan jumlah bakteri total Coliform dan Escherichia coli di bawah sinar matahari dari 1100 menjadi 0 
dengan peningkatan temperatur pada penjemuran di bawah sinar matahari dari $28^{\circ} \mathrm{C}$ sampai $57^{\circ} \mathrm{C}$. Kadar logam Fe dari semula 0,048 ppm turun menjadi 0,030 ppm. Kondisi optimum penyerapan selama 5 jam penjemuran di bawah sinar matahari pada kondisi yang baik dan paling tidak mencapai temperatur $55^{\circ} \mathrm{C}$. Prosentase penurunan logam $\mathrm{Fe}$

akibat bakteri total Colifortn dan Escherichia coli dalam air sebesar $1,14 \%$

Ozon merupakan senyawa oksigen yang terbentuk dari tiga atom oksigen (O3) dan mempunyai sifat sebagai oksidator kuat. Secara alamiah ozon terbentuk melalui dua cara yaitu melalui bantuan radiasi sinar ultraviolet matahari pada atmosfer bumi dan kilat yang terjadi di udara. Proses ozonisasi dalam pengolahan air minum dilakukan berdasarkan prinsip pembentukan ozon secara alamiah. Melalui dua cara diatas, ikatan atom dari 3 molekul oksigen (O2) akan terpecah dan membentuk 2 molekul ozon (O3). Ikatan atom yang membentuk ozon sangat lemah sehingga ozon yang terbentuk dapat cepat kembali menjadi oksigen $(\mathrm{O} 2)$.

Hal ini menyebabkan ozon mempunyai sifat oksidator yang kuat.

\section{3.c Kondisi Saat Ini}

Pengolahan yang biasa dilakuakan PDAM meliputi beberapa fasilitas yang dimiliki antara lain : Intake, Menara Air, Clarifier, Pulsator, Filter, dan Reservoir. Semua peralatan - peralatan tadi dapat dioperasikan melalui sistem komputer yang ada. Selain berbagai macam peralatan, PDAM juga menggunakan bahan kimia seperti kaporit dan trawas dalam proses pengolahan air bersih. Sistem ini biasanya memerlukan biaya yang relatif mahal dan susah diterapkan oleh masyarakat umum.

Sumber

(http://amarikhsanudin.blogspot.com/2011/09 /proses-pengolahan-air-baku-menjadiair.html)

Secara ringkas sistem Penjernihan Air Dengan Saringan Pasir dan Desinfektan Alami menggunakan komponen - komponen utama antara lain :
1. Intake

2. PenjernihanPertama

3. Bangunan Penenang

4. PenjernihanKedua
5. Bangunan

Pengaduk

6 Reservoir

Bawah Reservoir

7.
Juga menggunakan desinfektan alami yang berupa biji kelor. Sistem ini merupakan sistem yang ekonomis dan juga mudah diterapkan oleh masyarakat umum.

Desinfeksi adalah proses yang bertujuan untuk membunuh mikroorganisme patogen yang terdapat di dalam air baku yang masuk ke dalam instalasi pengolahan air minum. Proses ini tidak berlaku bagi mikroorganisme yang berada dalam bentuk spora. Terdapat berbagai metode untuk melakukan desinfeksi, 
antara lain dengan penggunaan zat pengoksidasi (ozon, halogen, senyawa halogen), kation dari logam berat (perak, emas, merkuri), senyawa organik, senyawa berbentuk gas, dan pengolahan fisik (panas, $\mathrm{UV}, \mathrm{pH})$.

Hal yang perlu dipertimbangkan dalam pemilihan filter air desinfektan yang akan digunakan adalah kemampuan desinfektan untuk memerangi kontaminasi yang terjadi setelah pengolahan pada sistem distribusi air sehingga desinfektan yang terpilih harus memiliki kekuatan desinfeksi yang tersisa di dalam air selama proses distribusi terjadi.

\section{Pembahasan}

\subsection{Prinsip Kerja}

Melihat latar belakang bahwa kebutuhan air bersih untuk masyarakat di Indonesia, terutama di sekitar daerah aliran sungai daerah lainnya yang sangat kurang memanfaatkannya, perlu buat sebuah sistem filtrasi yang mudah dilaksanakan oleh masyarakat secara umum. Maka Penjernihan Air Dengan Pasir dan Desinfektan Alami merupakan inovasi sistem pemurnian alami dengan metode saringan pasir ditambahkan dengan biji kelor dan cahaya matahari sebagai desinfektan. Konsep ini mengembangkan dari sistem pasir yang menyaring air kotor menjadi air bersih melewati saringan pasir dengan memanfaatkan gaya uplift air, sehingga air bergerak dari arah bawah ke atas. Saringan pasir disebut juga Rapid Sand Filter, yaitu penjernih anair yang dapat menghasilkan debit air hasil penyaringan yang lebih banyak daripada saringan pasir lambat.

Sumber air baku yang digunakan yaitu berasal dari air sungai dengan menggunakan sistem free intake. Air sungai akan masuk melalui pintu intake dan langsung menuju ke kantung lumpur versi mini, karena kantung lumpur ini berfungsi mengendapkan lumpur tahap pertama sebelum masuk ke sistem saringan pasir dan berukuran lebih kecil dibandingkan dengan kantung lumpur untuk kebutuhan air irigasi.

Untuk penyaringan sendiri dibagi menjadi 3 tahap, yang pertama penyaringan dengan pasir dan agregat kasar untuk mengendapkan lumpur dan butiran - butiran yang berukuran sedang, kemudian tahap dua ada filter dari arang, ijuk, dan pasir.

Sebenarnya sistem ini mengadopsi dari sistem sumur buatan masyarakat di desa desa secara tradisional dan kelemahannya yaitu air yang ada di sumur ini berkualitas tidak lebih baik dari air sungai yang mengandung zat - zat yang kurang baik apabila langsung dikonsumsi oleh masyarakat.

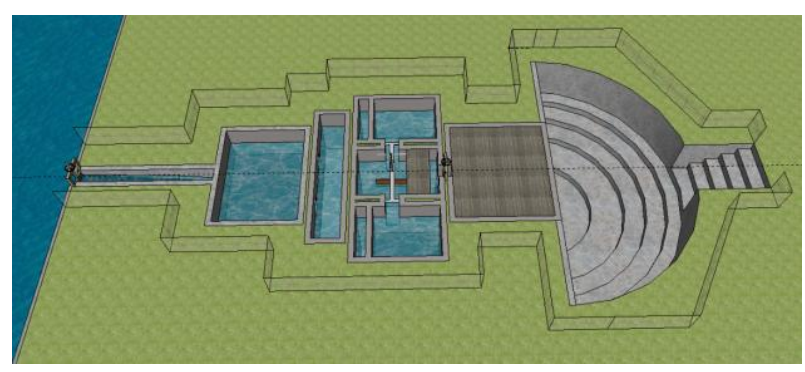

Gambar 1. Tampak Atas Bangunan 


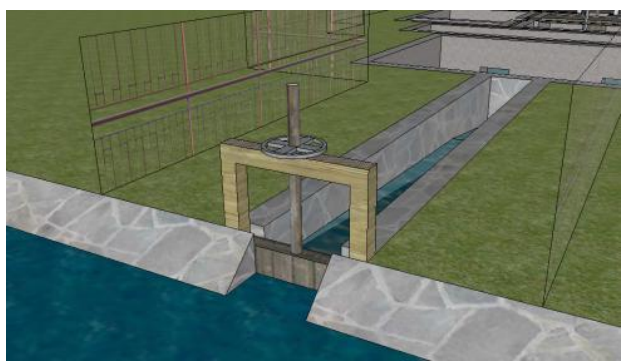

\subsection{Bangunan Penangkap Air}

Air diambil menggunakan sistem free intake yaitu dengan mengalirkan air sungai langsung ke tempat filtrasi yang pertama dengan mengandalkan gravitasi bumi, sehingga tidak memerlukan tenaga tambahan yang biasanya menggunakan pompa, sebelum memasuki ke sistem penjernihan ini, air akan melewati kantung lumpur, yang berfungsi untuk mengendapkan lumpur - lumpur berukuran besar, sehingga diharapkan tidak terjadi sedimentasi secara cepat yang akan terjadi di sistem pembersihan ini dan memperpanjang usia perawatan.

Bangunan ini berbentuk seperti saluran irigasi pada umumnya, menggunakan pasangan batu sebagai bahan dasarnya, dan dengan bentuk permukaan trapesium. Serta diupayakan bangunan yang kedap air dengan pengunaan spesi yang kedap air pula $1: 2$ atau 1:3, hal ini sangat penting diperhatikan mengingat bangunan penangkap air ini merupakan tempat pertama kali menerima/menyimpan air dari sungai apabila terjadi kebocoran/perembesan dari bangunan tersebut akan terjadi keterlambatan dalam proses penyaringannya.

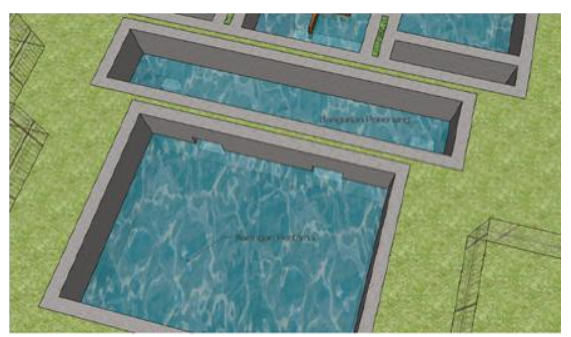

\section{Gambar 2. Saluran Intake}

\subsection{Penjernihan Tahap Pertama}

Air sungai yang telah melewati saluran penangkap, maka akan masuk ke penjernihan tahap pertama yang berisi batu kerikil dan pasir. Air akan masuk melalui bawah penjernihan dan mengandalkan gaya upflow air untuk melewati penjernihan tersebut. Dengan mempertimbangkan koefisien permeabilitas tanah, maka akan terjadi kehilangan energi yang dapat mengurangi debit aliran. Dari penjernihan ini diharapkan dapat menyaring lumpur yang terbawa oleh air dan belum sempat diendapkan di kantong lumpur.

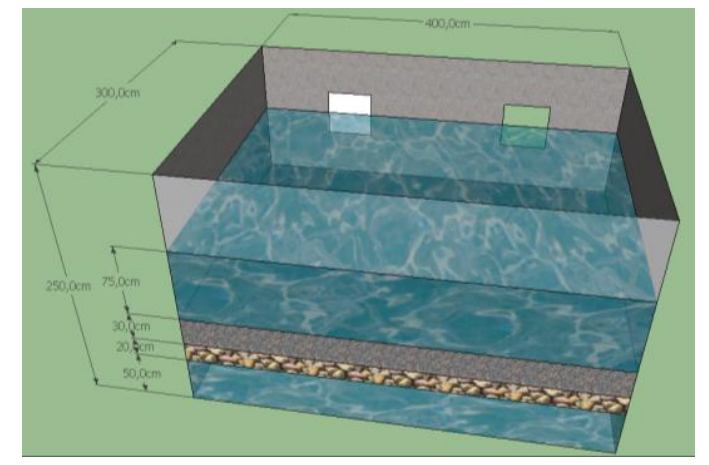

\section{Gambar 3. Detail Penjernihan Pertama}

\subsection{Bangunan Penenang}

Untuk menjaga kestabilan aliran air di tahap selanjutnya, maka diperlukan bangunan penenang untuk mengumpulkan air terlebih dahulu. 


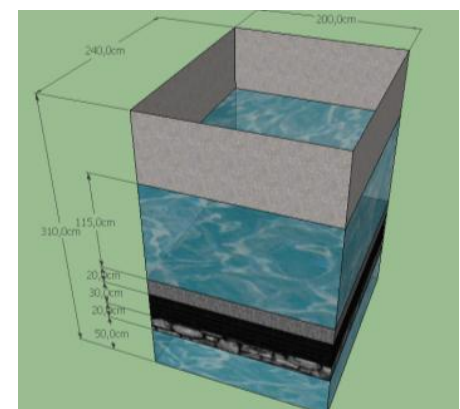

Gambar 4. Posisi Bangunan Penenang

\subsection{Penjernihan Tahap Kedua}

Penjernihan tahap kedua terdiri dari 3 lapisan, lapisan paling bawah yaitu arang, selanjutnya ada ijuk, dan paling atas pasir. Seperti penjernihan tahap pertama, akan terjadi kehilangan energi dikarenakan lapisan - lapisan pada penjernihan tahap kedua.

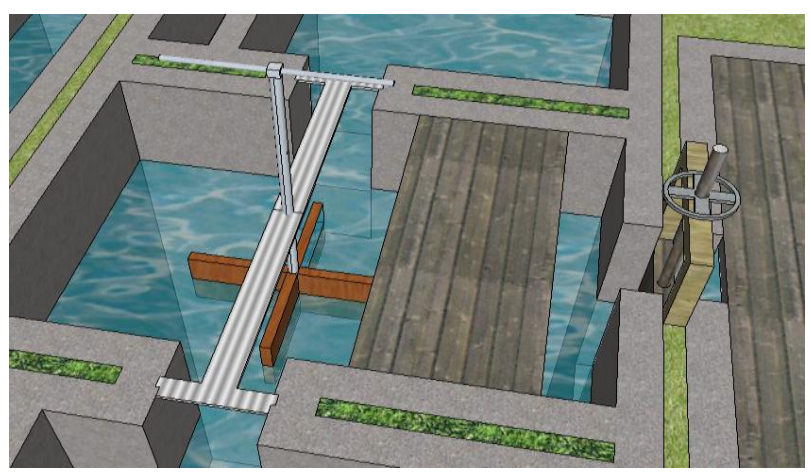

Gambar 5. PenjernihanKedua

\subsection{Bangunan Pengaduk Desinfektan}

Bangunan pada tahap ini berfungsi untuk tempat desinfeksi air baku terhadap kuman dan bakteri yang masih terkandung di air. Koagulan yang digunakan dalam sistem ini memanfaatkan koagulan alami, yaitu biji kelor.

Biji kelor diproses menjadi serbuk yang biasa dijual di internet walaupun masih sedikit. Tujuan lain dari biji kelor ini adalah sebagai pengganti trawas dan membuat air yang dihasilkan lebih alami dibandingkan menggunakan trawas. Dalam bangunan ini juga ditambahkan pengaduk berupa kincir air dengan tenaga manual, sehingga ketika mengaduk dan mencampur dapat lebih terkontrol oleh pengguna.

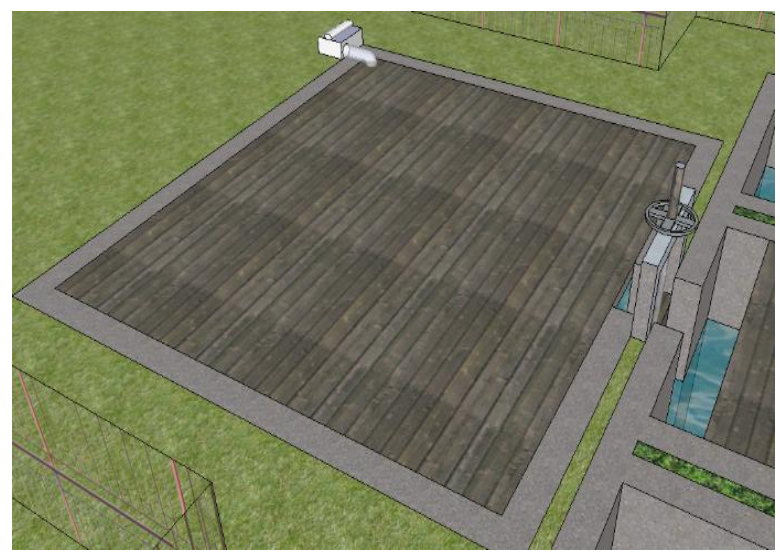

Gambar 6. Bangunan Pengaduk

\subsection{Reservoir Bawah}

Setelah melalui penyaringan dan pencampuran desinfektan, maka air akan ditampung di bagian reservoir bawah tanah. Dalam reservoir ini juga akan terjadi pengendapan dari kotoran yang tergumpal akibat reaksi sari biji kelor. Setelah ditampung di reservoir bawah maka selanjutnya akan dialirkan ke reservoir atas. Pada waktu pengaliran harus juga diperhatikan, supaya air mengalir dengan tenang dan tidak gerakan/gelombang yang bisa memepengaruhi kejernihan air yang ditampung di reservoir bawah.

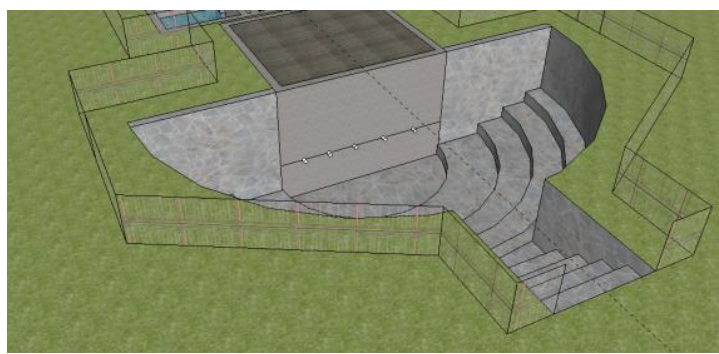




\section{Gambar 7. Reservoir Bawah Dalam}

\section{Keadaan Terbuka Dan Tertutup}

Tempat pengambilan

Untuk tempat pengambilan didesian untuk mempermudah warga, seperti gambar di bawah ini:

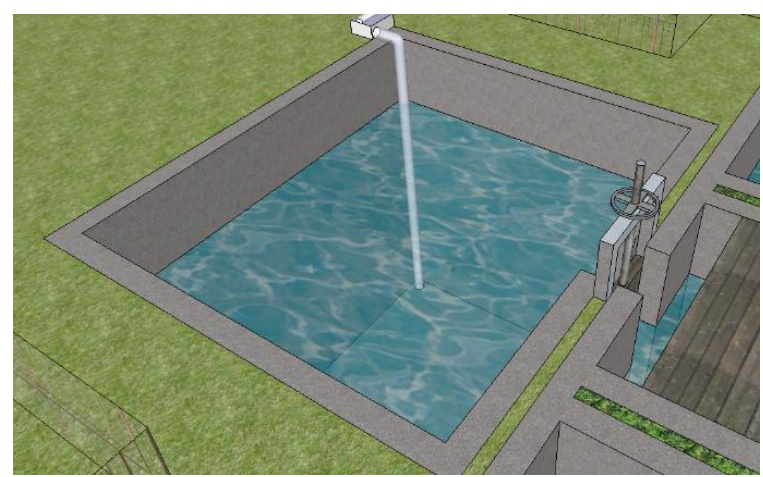

Gambar 8. Tempat Pengambilan Air

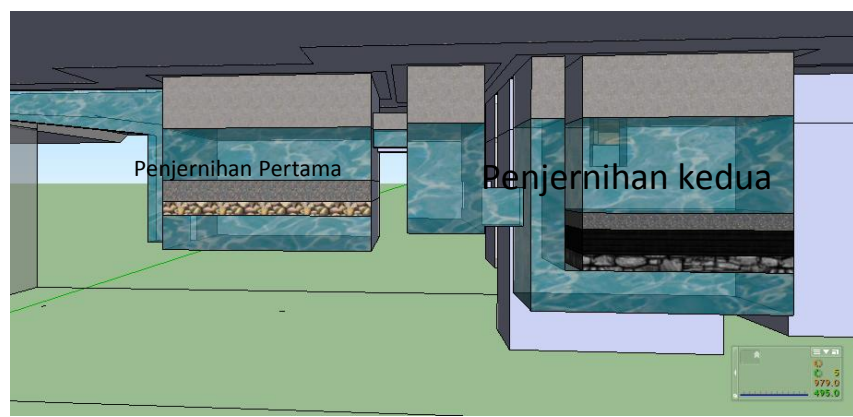

Gambar 9. Cara Kerja Penjernihan Air Mengalir Dari Kiri Ke Kanan

\section{Pemeliharaan / Maintanance.}

Perawatan dan pemeliharaan Bangunan

Bangunan ini perlu perawatan berupa penggantian penjernihan secara periodik, yaitu berupa batu kerikil, pasir, arang dan ijuk. Tidak hanya itu, pengurasan bangunan juga perlu dilakukan untuk membersihkan kotoran - kotoran yang mengendap di bagian bawah bangunan. Untuk mempermudah dalam perawatan, bagian bawah penjernihan akan diletakan baja dengan bentuk jaring, pengurasan agar dilakukan dalam jangka waktu yang tidak begitu lama dan bisa dilihat tingkat sendimentasi/endapan lumpurnya yang berada di baik bangunan intake maupun pada bangunan yang lainnya.

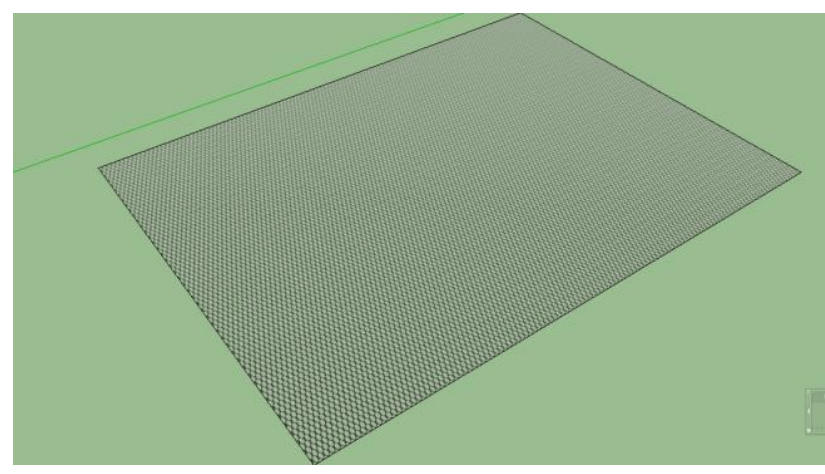

\section{Gambar 10. Baja Dengan Bentuk Jaring}

\section{Sebagai Alas Saringan}

Baja dengan bentuk jaring ini yang berfungsi sebagai alas saringan air paling bawah dimaksudkan untuk menyaring kotoran/limbah jangan samapai bisa ikut/masuk ke dalam air yang sudah di saring dengan beberapa tahapan diatas, serta dimaksudkan dengan bahan dari baja ini agar kuat menahan beban diatasnya serta kuat terhadap karat karena air yang disaring/masuk kadar kimianya beragam.

\section{PENUTUP}

Dalam konsep ini desain Penjernihan Air Dengan Saringan Pasir dan Desinfektan Alami memanfaatkan gaya angkat air dan menggunakan sistem penjernihan pasir cepat dengan berbagai lapisan yang dapat mengurangi kotoran dalam air. Desinfektan 
yang digunakan adalah biji kelor sebgai pengganti trawas.

Diharapkan dengan dirancangnya konsep ini dapat menanggulangi

kebutuhan air minum masyarakat umum di

sekitar dareah aliran sungai.

\section{Teknik Implementasi Gagasan}

Gagasan Penjernihan Air Dengan Saringan Pasir dan Desinfektan Alami ini dapat diimplementaskan dengan baik apabila didukung oleh hal-hal sebagai berikut :

1. Kesadaran masyarakat untuk memanfaatkan air sungai sebagai sumber air baku

2. Kerjasama berbagai bidang yang bersangkutan, mulai dari masyarakat sampai Pemerintah Daerah.

\section{Prediksi Keberhasilan Gagasan}

Dengan direalisasikannya Penjernihan Air Dengan Saringan Pasir dan Desinfektan Alami ini, maka akan didapatkan dua keuntungan dari pihak Pemerintah Daerah, yang pertama adalah mengatasi kebutuhan air minum pada masyarakat, dan menambah nilai guna dari sungai itu sendiri.

\section{Daftar Pustaka}

1. Almatsier, Sunita. 2005. Penuntun Diet. Jakarta : Gramedia Pustaka Utama.

2. Arikunto, S. 2008. Prosedur Penelitian Suatu Pendekatan Praktek. Yogya : Rineka Cipta.
3. Anonim.

(http://amarikhsanudin.blogspot.com/2011

109/proses-pengolahan-air-baku-menjadiair.html)

4. Untung, Onny. 2011. Menjernihkan Air

Kotor. Niaga Swadaya : Jakarta.

5. Sutrisno, Totok,dkk. 2006. Teknologi

Penyediaan Air Bersih. Rineka Cipta :

Jakarta. 